\title{
Long-term heat treatment of collector bars for aluminium electrolysis: impact on microstructure and electrical properties
}

\author{
Jonas Hankel ${ }^{1}$ D . Sandra Kernebeck ${ }^{1} \cdot$ Friederike Deuerler $^{1} \cdot$ Sebastian Weber $^{2}$
}

Received: 14 May 2020 / Accepted: 20 August 2020 / Published online: 29 August 2020

(c) The Author(s) 2020 OPEN

\begin{abstract}
In order to identify possible optimizations regarding the electrical energy efficiency of an aluminium electrolysis cell, the impact of service temperature on microstructure and electrical properties of the cell cathode was investigated. The investigations include experiments regarding the chemical composition, especially the content of carbon, the electrical conductivity and the microstructure at selected positions. Thermodynamic calculations were used to estimate local service temperatures and explain phase transformations and formations. It was found that due to the increased service temperature diffusion processes of carbon took place to a particular extent between cast iron and collector bar. As a result, the carbon content in the collector bar changed from 0.06 to $1.05-1.4 \mathrm{wt} \%$, while in the cast iron a reduction from 3.47 to $<1.50 \mathrm{wt} \%$ took place. These processes led to isothermal phase transformations and formations, that changed the matrix of the collector bar from austenitic with low content of ferrite to an austenitic matrix accompanied by precipitation of secondary, predominantly allotriomorphic cementite at service temperature. It was then shown that this has a negative effect on collector bar and decreases the electrical conductivity by up to $26 \%$. It was also discovered that graphite spheroidization within the grey cast iron has a positive effect on its electrical conductivity, which has increased by 52 $\%$. The results provide the basis to gain an understanding of the carbon diffusion related processes within the cathode of an electrolysis cell and reveal further potential to increase the energy efficiency of primary aluminium production.
\end{abstract}

Keywords Aluminium electrolysis · Collector bar · Energy efficiency · Electrical conductivity - Diffusion · Long-term heat treatment

\section{Introduction}

Aluminium and aluminium alloys are well-known lightweight materials with a broad spectrum of applications ranging from e.g. construction, to packaging, to transport and electrical equipment. A key benefit of aluminium, besides high specific strength, is its good recyclability. The worldwide demand, however, cannot be covered by secondary aluminium, as a direct consequence of economic growth, an increasing spectrum of applications and requirements on quality and cleanliness of the material. Therefore, primary production of aluminium still plays a major role in this economic sector and will continue to do so in the future. A major industrial process used for primary production of aluminum is the Hall-Héroult process, which is dependent on fused-salt electrolysis in cells operated with cryolite $\left(\mathrm{Na}_{3} \mathrm{AlF}_{6}\right)$ as the electrolyte in a typical temperature range between 950 and $970{ }^{\circ} \mathrm{C}$ [1]. A schematic drawing of such an electrolysis cell is given in Fig. 1 . The process is fully dependent on electrical energy and consumes about $15 \mathrm{kWh}$ per $\mathrm{kg}$ of pure metal [2]. Because of its high dependence on electrical energy, a comparatively costly energy carrier, and the high demand, cell efficiency exerts a main influence on the overall productivity

$\triangle$ Jonas Hankel, hankel@uni-wuppertal.de | 'Lehrstuhl Werkstofftechnik, Bergische Universität Wuppertal, Gaußstraße 20, Wuppertal, Germany. ${ }^{2}$ Lehrstuhl Werkstofftechnik, Ruhr-Universität Bochum, Universitätsstr. 150, Bochum, Germany. 
Fig. 1 Schematic drawing of an aluminum electrolysis cell. In the right the expanded cathode is rotated by $90^{\circ}$ to show the compound of cast iron and collector bar

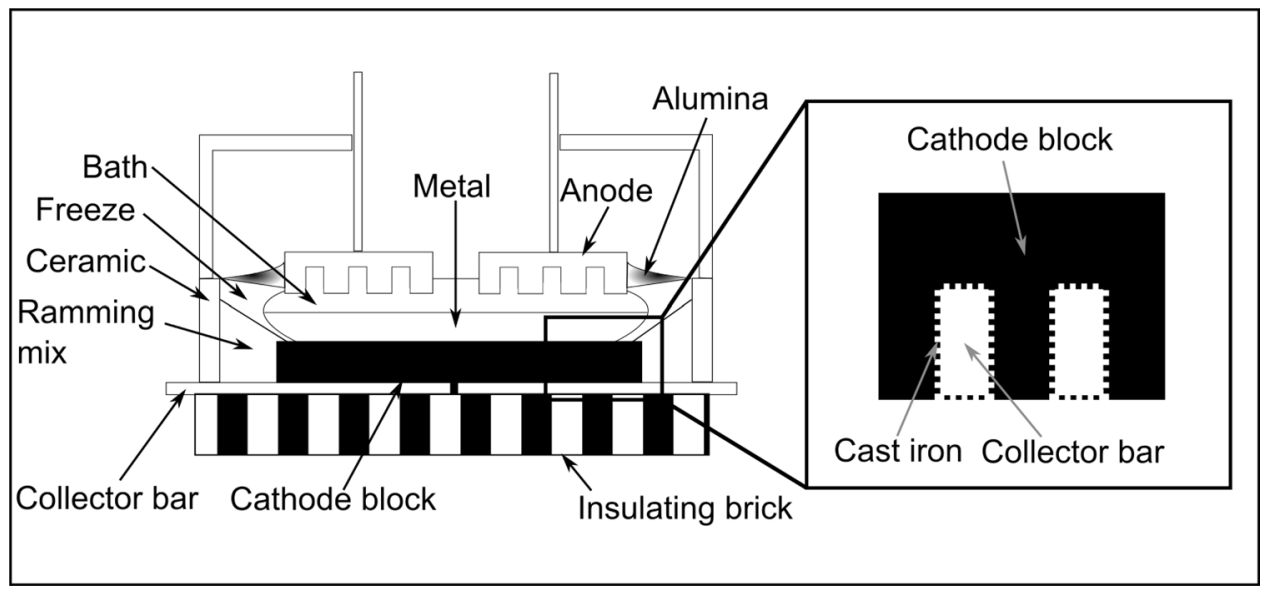

of aluminium production. Thus, it makes sense to investigate all components of the electrolysis cell from a materials science point of view, to unveil potentials for a further increase of its efficiency.

The electrolysis cell consists of different components and materials. At the bottom, insulating bricks form the basis of the cell, above which the cathode is situated. The cathode consists of the cathode block and the collector bars. Additionally, a third component is needed to establish a mechanical connection and a stable electrical contact between the cathode block and the collector bars. The cathode block is typically made of carbon and the collector bar is most commonly made of low alloyed steel, with a high conductivity for electrical current. The connecting material is a high-carbon casting iron alloy in most production sites. Cathode blocks (prebaked blocks) are available in three different types: anthracite, graphitic and graphitized. The cathode blocks used in this study are made of graphite and pitch binder, providing an electrical resistivity of $19 \mu \Omega \mathrm{m}$ at $20^{\circ} \mathrm{C}$ [3] $(0.0531 / \mu \Omega \mathrm{m})$. To connect the collector bars with the cathode block, grey cast iron is used (Fig. 2a). Prior to casting the connecting material, a distance between collector bar and cathode block is created, using aluminium silicate wool acting as a spacer. After pre-heating the collector bars, the cast iron flows between collector bar and cathode block, resulting in a mechanical connection and, even more importantly, in the formation of a stable electrical contact between graphite and collector bar.

For usage in the electrolysis cell, the cathode is rotated $180^{\circ}$ after the casting process. Above the cathode, the molten aluminium is connected to the anode during fused-salt electrolysis. The direct current passes the anode, the electrolyte, the molten aluminium, and
Fig. 2 Material compound of graphite and collector bar with cast iron as the connecting material (a). The cathode block is flipped upside down in the electrolysis cell. Cross section of the collector bar after usage in a cell (b). At the marked positions (circles), samples have been taken for investigation and labelled according to material and position

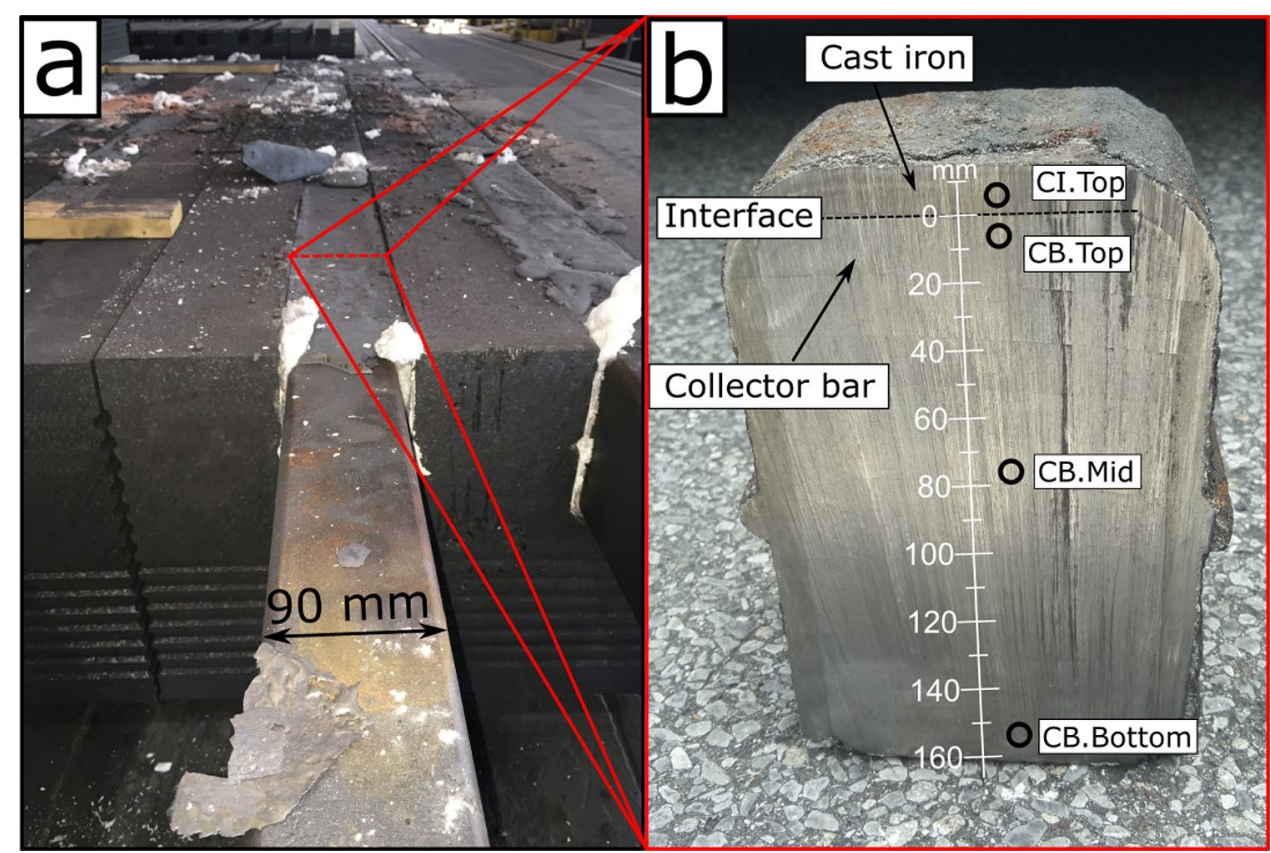


finally the cathode, considering the technical direction of the electrical current. The cathode block with the cast iron and the collector bars conducts the current out of the cell [4]. The current rating is up to $600 \mathrm{kA}$ with a typical voltage of $4-5 \mathrm{~V}$ [5].

To save energy, a high efficiency of the process, and particularly of the electrolysis cell, is required. In this context, Haraldsson et al. investigated productionrelated energy efficiency measures in the aluminium industry [6]. A few authors have also included the cathode in their investigations, mainly focusing on choice of materials, cathode design and bonding techniques. The material of the cathode (graphitized carbon vs. anthracitic carbon) $[7,8]$ and novel structure cathodes with different shapes [9-11] were identified to influence the energy requirement in a positive way. To optimize the structure, the conductive structure and the size of collector bar and cathode block can be changed as well. A regular current flow between collector bar and cathode block is shown to be the effect of these structural adjustments [6, 12]. Additionally, electrically insulating regions between cathode block and collector bar [9] as well as heatproof concrete [13] are discussed in the literature and are assumed to be able to reduce the horizontal current flow [6]. While the connection between cathode block and electrolyte has been investigated in detail in several studies [14, 15], the solid-solid interfaces between collector bar, cast iron and cathode block have not been studied in detail before.

Therefore, this study focuses on the materials compound of the cathode, investigating primarily the collector bar and the cast iron interlayer in two different conditions. First, the initial state of the materials compound prior to its use in an electrolysis cell is investigated. For comparison, the same compound is examined at different positions after a service time of several years within a cell operated at a targeted constant temperature of $960^{\circ} \mathrm{C}$ [16]. The boundary conditions are therefore equivalent to an isothermal long-term heat treatment, even though the detailed temperature field within the collector bar cross section is not known from experimental investigations. The ambition of this study is to discover the microstructural changes within the cathode resulting from the longterm heat treatment as follows:

- To what extent does the operation of the cell lead to grain growth in the collector bar?

- Does diffusion of alloying elements take place and if so, to what extent?

- How does the microstructure evolve during long-term tempering?

- Does the electrical conductivity change and if so, to what extent?
The whole investigation is to serve as a basis for future optimization of cathode materials with the ambition of increasing cell efficiency. Experimental data shall be provided as key information for the validation of computer simulations.

\section{Materials and methods}

Specimen of the Collector bar in its initial state, was taken from a fresh collector bar. A specimen of the cast iron in its initial state was created by casting the material into a mould (diameter $47 \mathrm{~mm}$ ).

The chemical composition of the collector bar (initial state) was measured with optical emission spectrometry (OES, company: Thermo Fisher Scientific, type: ARL 4460). The chemical composition of the cast iron (initial state) was measured using the Quik-Cup method by Heraeus [17].

The collector bar connected to the cast iron after operation in the electrolysis cell for 1939 days (5.4 years) was separated into different samples. The initial state of the collector bar material stems from a different batch from the state after use in the cell. To continue previous investigations [18], different positions within the cross section of the collector bar were evaluated. The positions were marked and named in Fig. 2b. OES analyses to measure the chemical composition have been carried out at all 4 positions. All samples of the collector bar and cast iron were embedded at $180^{\circ} \mathrm{C}$ (company: Presi, type: mecapress 3 ) in epoxy resin prior to metallographic preparation. For polishing, the samples were handled with diamond suspension (particle size: $1 \mu \mathrm{m}$ ) and lubricant. The Vickers hardness (HV10) was measured with an automatic hardness tester (company: ATM GmbH, type: Carat 930). An etchant ( 3 vol\% $\mathrm{HNO}_{3}, 97 \mathrm{vol} \%$ ethanol) was used to visualize grain boundaries. By using an optical microscope, a stereo microscope (company: Leica Microsystems GmbH, type: DM 2000 M, S6D) and the software ImageJ (Version $1.48 \mathrm{v}$ ) the microstructure was analyzed. The grain size was measured according to DIN EN ISO 643 [19]. The light microscopic images of the collector bar after usage in the cell contained light areas, presumably cementite. An image analysis was conducted to quantify the amount of secondary, predominantly allotriomorphic cementite in the metallic matrix at different positions in the collector bar, using the software ImageJ. Therefore, the images were binarized and subsequently the area fraction of cementite was estimated by point analysis.

For detailed investigations, a scanning electron microscope (SEM) (company: Tescan $\mathrm{GmbH}$, type: Vega3SBH) and an energy dispersive $\mathrm{X}$-ray spectrometer (EDS) (company: Bruker, type: XFlash 5030, software: Quantax) 
were used. The working distance varied between $8 \mathrm{~mm}$ (SEM) and $15 \mathrm{~mm}$ (EDS). The acceleration voltage was set between $10 \mathrm{kV}$ and $15 \mathrm{kV}$. The microstructure and the chemical composition of the different samples were analyzed at several magnifications up to a maximum value of $15,000 \times$. For phase identification a diffractogram of the collector bar after service time was recorded using a Bruker D2 Phaser X-ray diffractometer operated at $30 \mathrm{kV}$ and $20 \mathrm{~mA}$ to generate $\mathrm{Cu} \mathrm{K}(\mathrm{a})$ radiation. The angle range was $20-100^{\circ} 2 \theta$ with a step size of $0.02^{\circ} 2 \theta$ and an integration time of $2 \mathrm{~s}$. Experiments were conducted with a sample rotation of $10 \mathrm{rpm}$. Thereafter, reflections were matched with phase patterns from the ICCD database (ICCD: International Centre for diffraction data).

A phase diagram and the equilibrium volume fraction of cementite depending on the temperature were calculated using the software Thermo-Calc (Version: 2019.1.36671604 , database:TCFe7). This tool uses thermodynamic databases and evaluates phase diagrams using the established CALPHAD method where the thermodynamic properties of each phase are described through the Gibbs free energy. The phases graphite and diamond were rejected to consider the metastable condition of the collector bar steel. For the calculation, the chemical composition of the collector bar after usage in the cell (CB.Top, Fig. 1b) was used. Additionally, service temperatures at different areas in the collector bar have been calculated by using the locally measured chemical composition and the quantified amount of cementite at those areas.

For electrical conductivity measurements, square samples $(5 \mathrm{~mm} \times 5 \mathrm{~mm}$ ) with a length between 20 and $23 \mathrm{~mm}$ were taken from the composite material at the marked positions (Fig. 1b) as well as from the initial state of collector bar and cast iron. Due to the dimensions of the samples it can be assumed that the measuring current is almost one-dimensional. The samples were cleaned in ethanol in an ultrasonic bath to measure the electrical resistivity using the Linseis LSR-Platform (company: Linseis Messgeräte $\mathrm{GmbH}$, type: LSR-3). The instrument uses a fourterminal measurement with direct current to supress parasitic influences. The measurements were taken at room temperature and with a measuring current of $100 \mathrm{~mA}$. By calculating the reciprocal, the electrical resistance was converted into the electrical conductivity.

\section{Results}

\subsection{Variation of the chemical composition}

The chemical composition of collector bar and cast iron is shown in Table 1. The initial state of the collector bar contains only little amounts of alloying elements. The cast iron contains $3.47 \mathrm{wt} \%$ carbon, $2.66 \mathrm{wt} \%$ of silicon, about 0.8 wt $\%$ manganese and high levels of phosphorus [20].

The chemical composition of the collector bar after usage in the electrolysis cell differs from the initial state. Depending on the position, the content of carbon varies (Table 1). In contrast to position CB.Top (1.28 wt\%), position CB.Mid contains more carbon (1.4 wt\%). Position CB. Bottom includes less carbon (1.05 wt\%) than the two other positions. Compared to the initial state $(0.32 \mathrm{wt} \%)$ the collector bar after usage in the electrolysis cell contains more $\mathrm{Mn}(0.34 \mathrm{wt} \%)$. However, one has to keep in mind the different batch of initial state and after service material.

Using the area ratio of cast iron $\left(A_{C l}=4700 \mathrm{~mm}^{2}\right)$ and collector bar $\left(A_{C B}=14400 \mathrm{~mm}^{2}\right)$ in a cross section as seen in Fig. $2 b$ an average amount of carbon was calculated by $C_{\text {Avg }}=\left(A_{C l} * C_{C l \text {.nitial }}+A_{C B} * C_{C B \text {.Initial }}\right) /\left(A_{C l}+A_{C B}\right)$, With $A$ being the area and $C$ being the amount of carbon in their initial states. The resulting average amount of carbon was $C_{\text {Avg }}=0.9 w t \%$.

\subsection{Investigation of the microstructure}

The collector bar in its initial state has a ferritic matrix with a low amount of pearlite (Fig. 3a) and a grain size of $34 \pm 3 \mu \mathrm{m}$. The microstructure of the cast iron in its initial state (Fig. 3a, b) contains irregularly distributed, lamellar graphite in a ferritic matrix. For both the cast iron and the collector bar, the microstructure changes drastically over the service time of 5.4 years.
Table 1 Chemical composition of collector bar (col. bar) and cast iron in wt\%

\begin{tabular}{lllllll}
\hline Pos. & $\mathrm{C}$ & $\mathrm{Si}$ & $\mathrm{S}$ & $\mathrm{P}$ & $\mathrm{Mn}$ & $\mathrm{Fe}$ \\
\hline Cl.Initial [18, 20] & 3.47 & 2.66 & 0.03 & 0.84 & 0.82 & Bal. \\
CI.Top $^{\mathrm{a}}$ & $<1.50$ & $2.33 \pm 0.04$ & $0.02 \pm 0.01$ & $1.19 \pm 0.15$ & $0.68 \pm 0.01$ & Bal. \\
CB.Initial & 0.06 & 0.05 & 0.01 & 0.01 & 0.32 & Bal. \\
CB.Top & $1.28 \pm 0.01$ & 0.01 & 0.01 & 0.01 & 0.34 & Bal. \\
CB.Mid & $1.4 \pm 0.01$ & 0.01 & 0.01 & 0.01 & $0.34 \pm 0.01$ & Bal. \\
CB.Bottom & $1.05 \pm 0.02$ & 0.01 & 0.01 & 0.01 & 0.34 & Bal. \\
\hline
\end{tabular}

The chemical composition of the collector bar after usage in the cell was measured with OES

${ }^{a}$ Measured with calibrated OES grey cast iron programme 
Fig. 3 Initial state of the collector bar (a-c) and after service at CB.Top (d, e) with light microscopy (a, d, e) and SEM images for pearlite investigation $(\mathbf{b}, \mathbf{c})$. A corresponding XRD pattern (f) of the collector bar in the middle position after service time with the reflections matched to the phase patterns of ferrite and cementite
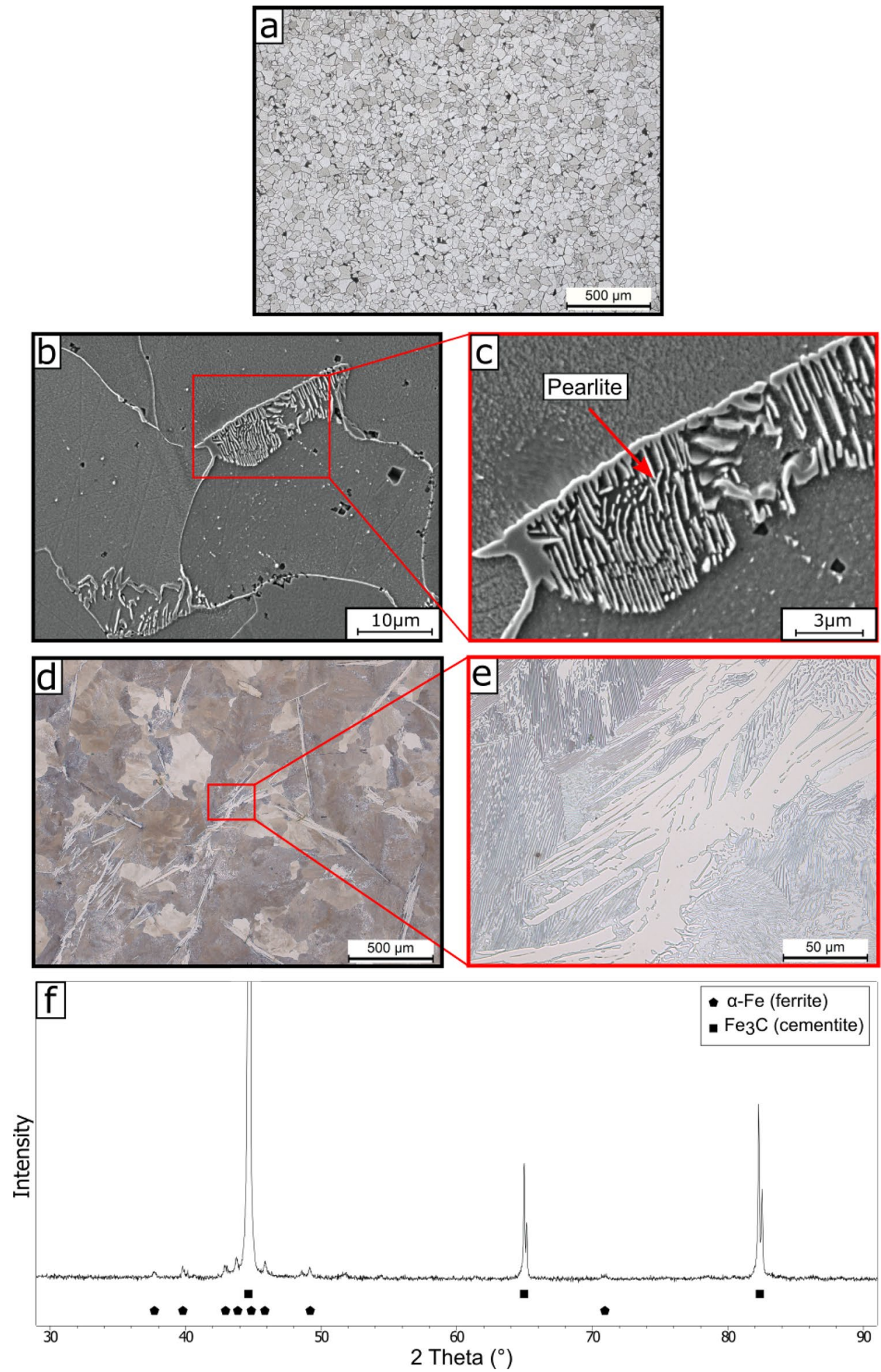

The collector bar after operation in the electrolysis cell (CB.Top) shows a pearlitic structure with massive plates of cementite (Fig. 3d, e), passing from the grain boundaries into the matrix [17]. The microstructure at CB.Mid and CB.Bottom is comparable with the one of CB.Top. The XRD measurement, that has been conducted on collector bar after service time, confirms that the microstructure is composed only of ferrite and cementite (Fig. 3f).

The grain size within the microstructure of the collector bar after usage in the electrolysis cell $(103-109 \mu \mathrm{m})$ is more than three times higher than the initial state assuming an almost equal condition of the two different batches. 
Furthermore, the grain sizes are virtually equal over the investigated cross section.

In the cast iron, the formerly lamellar graphite changes its shape and is almost spherulitic after the period of use (Fig. 4c, d).
The interface between cast iron and collector bar is characterized by the presence of pores and, towards the cast iron, inclusions (Fig. 5a, b). Position 1 (Fig. 5c) contains almost exclusively carbon (99.22 wt\%). Position 2 consists mainly of aluminium (44.23 wt\%) and oxygen
Fig. 4 Initial state of the cast iron $(\mathbf{a}, \mathbf{b})$ and cast iron at Cl.Top after usage in the electrolysis cell $(\mathbf{c}, \mathbf{d})$
Fig. 5 Interface of cast iron and collector bar $(\mathbf{a}, \mathbf{b})$. The SEM image (c) marks two types of inclusions. Corresponding hardness and EDS-scans $10 \mathrm{~mm}$ from the interface in each direction are additionally presented
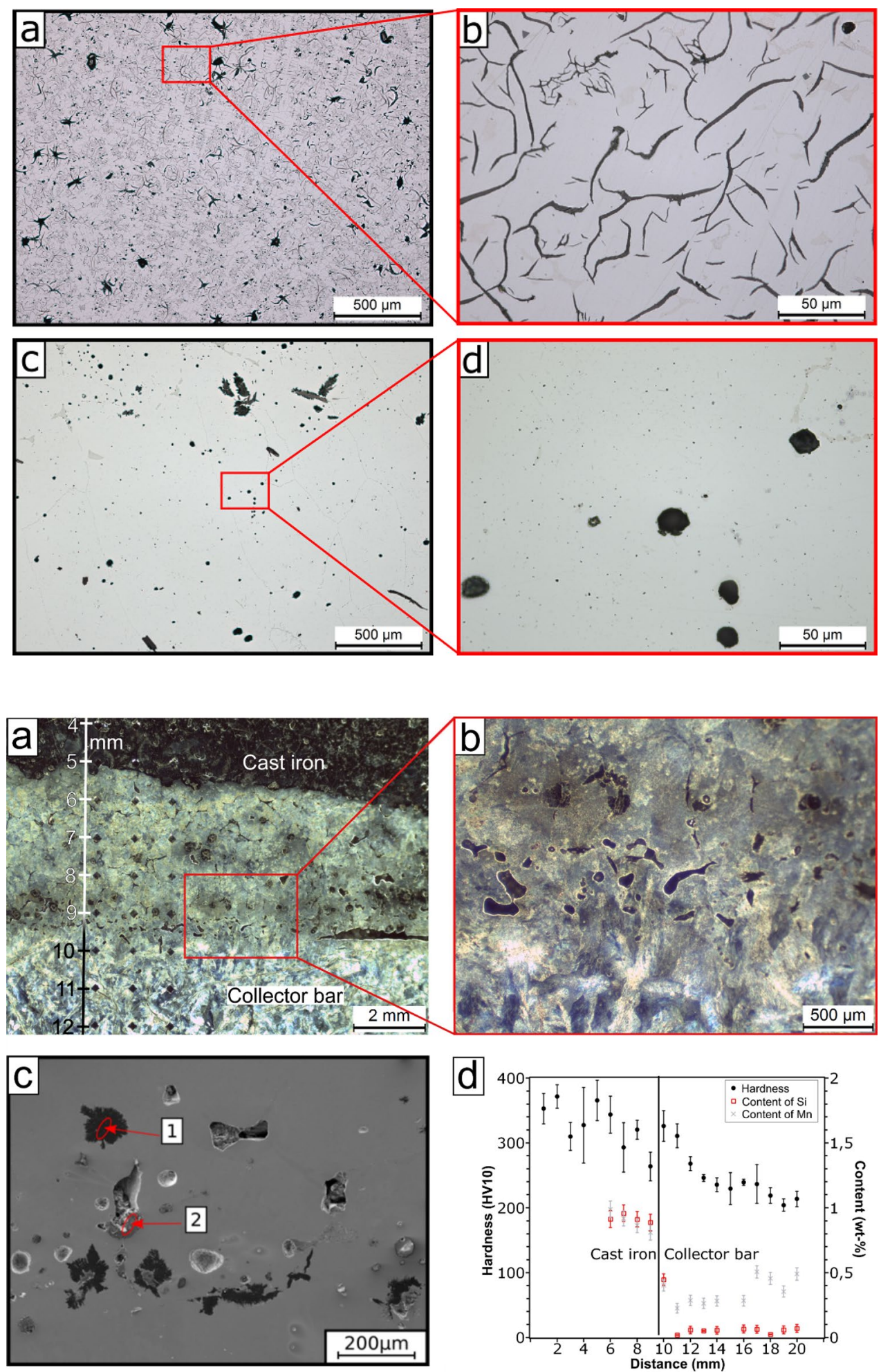
(49.97 wt\%). Figure $5 d$ includes the content of silicon and manganese measured with EDS from the cast iron into the collector bar. The cast iron (Fig. $5 \mathrm{~d}, 6-9 \mathrm{~mm}$ ) contains $0.92 \pm 0.03 \mathrm{wt} \% \mathrm{Si}$ and $0.89 \pm 0.08 \mathrm{wt} \% \mathrm{Mn}$. Within $2 \mathrm{~mm}$ the content declines to $0.05 \pm 0.02 \mathrm{wt} \% \mathrm{Si}$ and $0.27 \pm 0.02 \mathrm{wt} \% \mathrm{Mn}$ (Fig. $5 \mathrm{~d}, 11-16 \mathrm{~mm}$ ). While the results for $\mathrm{Mn}$ are in acceptable agreement with the measured OES results (Table 1), the results for $\mathrm{Si}$ in the cast iron are too low. However, it can be noted that there seems to be only a very small diffusion layer of the substituted elements $\mathrm{Si}$ and $\mathrm{Mn}$ in the range of $\approx 1 \mathrm{~mm}$. The comparatively thin diffusion layer cannot be precisely measured by OES (Table 1).

For investigations regarding the local service temperature at different positions in the collector bar, the area-\% of the secondary cementite was calculated (Table 2). It is assumed that the area-\% is comparable to the actual vol\%, because the analysis was performed on several images for each calculation point.

\subsection{Thermodynamic calculations}

The pseudobinary phase diagram (Fig. 6) includes the temperature between 500 and $1000^{\circ} \mathrm{C}$ with a varying content

Table 2 Area-\% of cementite and estimated service temperature at different positions in the collector bar

\begin{tabular}{lll}
\hline Position & Cementite (area-\%) & $\begin{array}{l}\text { Service tempera- } \\
\text { ture }\left({ }^{\circ} \mathrm{C}\right)\end{array}$ \\
\hline CB.Top & $2.74 \pm 0.87$ & $850-885$ \\
CB.Mid & $4.17 \pm 1.00$ & $863-902$ \\
CB.Bottom & $3.35 \pm 1.6$ & $731-803$ \\
\hline
\end{tabular}

of carbon up to $2 \mathrm{wt} \%$. The other elements were considered with the values measured in Table 1. In combination with the chemical composition and the area-\% of cementite at the investigated areas, the local service temperatures could be estimated by ThermoCalc (Table 2).

\subsection{Investigation of the electrical conductivity}

The electrical resistivity was measured at room temperature and then converted into the electrical conductivity. Table 3 shows the results of the different samples. The initial state of the collector bar exhibits the highest value $(7.251 / \mu \Omega \mathrm{m})$, the initial state of the cast iron the lowest value $(0.991 / \mu \Omega m)$. Compared to the initial state, the electrical conductivity of the collector bar decreased after operation in the electrolysis cell. The value at CB.Top, next to the cast iron, is lower than in the middle and at the bottom of the collector bar. Relative changes between initial states and the condition after long term heat treatment were calculated for both cast iron and collector bar.

Table 3 Electrical conductivity of the initial state of the collector bar and cast iron and of the different positions after service

\begin{tabular}{lll}
\hline Position & $\begin{array}{l}\text { Electrical conductivity }(1 / \\
\mu \Omega \mathrm{m})\end{array}$ & $\begin{array}{l}\text { Rel. differ- } \\
\text { ence }(\%)\end{array}$ \\
\hline Cl.Initial & 0.99 & 100 \\
Cl.Top & $1.51 \pm 0.01$ & 152 \\
CB.Initial & $7.25 \pm 0.10$ & 100 \\
CB.Top & $5.34 \pm 0.30$ & 74 \\
CB.Mid & $6.31 \pm 0.05$ & 87 \\
CB.Bottom & $6.42 \pm 0.10$ & 89 \\
\hline
\end{tabular}

Fig. 6 Phase diagram based on the collector bar (CB.Top). The dotted line represents the isothermal carbon diffusion process over the time of 5.4 years. At the beginning the matrix is mostly austenitic with a low amount of ferrite (1). With increasing carbon content, the composition eventually transforms into a fully austenitic matrix (2), accompanied by grain growth. At the end, the carbon content has increased so much, that precipitation of secondary cementite $\left(\mathrm{Fe}_{3} \mathrm{C}\right)$ occurs (3)
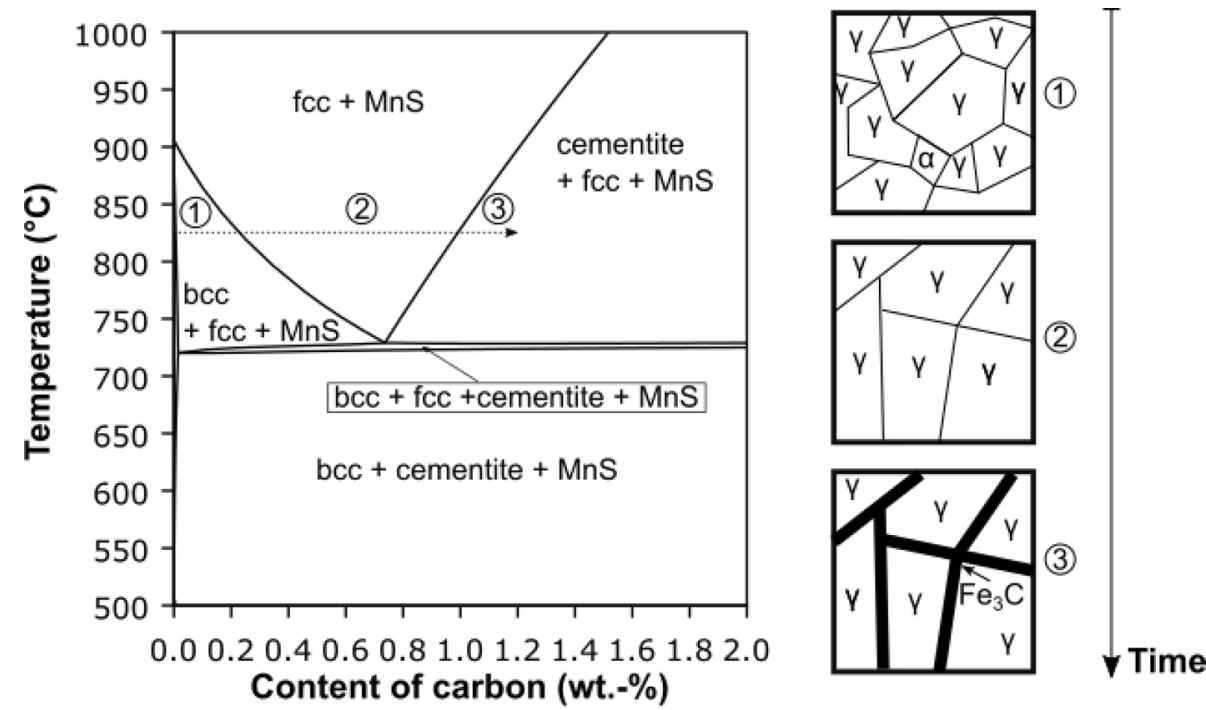

SN Applied Sciences A SPRINGER NATURE journal 


\section{Discussion}

\subsection{Change of microstructure by diffusion processes}

According to the ThermoCalc simulation at local service temperatures, the collector bar is austenitic with a low amount of ferrite at the start of service time, because the lowest local service temperatures are around $731-803^{\circ} \mathrm{C}$ and for the content of carbon at the beginning the austenite and ferrite window ranges from 717 to $890^{\circ} \mathrm{C}$ (Fig. 6). During the service time, the content of carbon increases isothermally up to $1.4 \mathrm{wt} \%$ (Table 1). An increment of carbon shifts the phase transformation-ferritic \& austenitic to fully austenitic - to lower temperatures because the system is getting closer to the eutectoid composition (Fig. 6). This leads to a fully austenitic collector bar with high carbon solubility. Eventually the carbon content surpasses the eutectoid composition and secondary cementite can be formed isothermally in addition to the austenitic phase. For example, for a temperature of $885^{\circ} \mathrm{C}$, cementite is precipitated when the content of carbon exceeds $1.16 \mathrm{wt} \%$ (Fig. 6) and for lower temperatures cementite is formed even earlier. XRD measurements of a sample at position CB.Mid indicate that only cementite and ferrite occur in the microstructure and that no graphitization or formation of other carbides has happened. The measured cementite is related to both the eutectoid cementite and the cementite plates. As explained, it is assumed that the latter is secondary, allotriomorphic cementite, formed isothermally during the application time. The calculated local service temperatures, based on the phase diagram and measured amount of cementite, are in accordance with this assumption. In contrast to this isothermal phase transformation and formation, pearlite is formed upon cooling after shutdown of the electrolysis cell.

The formation of perlite during cooling happens close to the equilibrium state because the electrolysis cell has stored an extremely high amount of thermal energy after shutting down and therefore the collection bar cools down very slowly, which prevents the formation of martensite or bainite. An earlier formation of pearlite at service temperature can be ruled out as the full cross section of the collector bar is isothermally kept at a temperature higher than the eutectoid one (Fig. 6). For that reason, the volume or area fraction of secondary cementite can be used to determine the local temperatures in the collector bar at service condition. The latter is an important measurement to validate simulations of the electrolytic process.

During the application time, carbon diffuses from the graphite (cathode block) and the cast iron to the collector bar, leading to an increased content of carbon in the collector bar after 5.4 years of operation in the electrolysis cell (Table 1). The diffusion coefficient $D$ is calculated with $D=D_{0} * \exp \left(-Q_{A} / R T\right)$ with the diffusion constant $D_{0}$, activation energy $Q_{A}$, gas constant $R$ and temperature $\mathrm{T}$ [21]. With the diffusion constant of carbon in $\gamma$-Fe $\left(D_{0}=0.23 \mathrm{~cm}^{2} / \mathrm{s}[21]\right)$ and $D=1.42 * 10^{-7} \mathrm{~cm}^{2} / \mathrm{s}$ the diffusion distance for carbon in $\gamma$-Fe after 1939 days at $886^{\circ} \mathrm{C}$ is $6.89 \mathrm{~cm}$. The width of the collector bar is $9 \mathrm{~cm}$ and the collector bar is surrounded on three sides by cast iron, thus it is safe to say that the diffusion affected the whole collector bar and that the diffusion has reached a point of saturation.

In contrast to carbon diffusion, there has been little to no observed diffusion of $\mathrm{Mn}$ and $\mathrm{Si}$, because these elements are substituted and not interstitial like carbon. At a raised temperature of between 1095 and $1347^{\circ} \mathrm{C}$, the diffusion of silicon in iron is described by $D=0.44$ * $\exp \left(200.83 /\left(R^{*} T\right)\right)[22]$, which results in a diffusion length of max. $4 \mathrm{~mm}$ in 1939 days. It is assumed that the actual diffusion length is shorter because of the lower temperatures at the collector bar and cast iron compared to the literature diffusivity of $1095-1347^{\circ} \mathrm{C}$. This assumption is in agreement with the EDS measurement, revealing a raised Si content in the collector bar only within $1 \mathrm{~mm}$ from the interface.

In contrast to the increased carbon content in the collector bar, the cast iron has a considerably lower carbon content compared to the initial state (Table 1). The grey cast iron programme for the OES is calibrated only up to a minimal carbon amount of $1.50 \mathrm{wt} \%$ and measurements with this programme showed an amount below $1.50 \mathrm{wt} \%$. Therefore, the exact carbon amount could not be measured, but the measurement shows a massive depletion of carbon in the cast iron in contrast to the high amount of $3.47 \mathrm{wt} \%$ in its initial state. A rough consideration of the volume ratios between cast iron and collector bar results in an average carbon content of $\approx 0.9 \mathrm{wt} \%$ over the entire volume. Looking at the measured amounts for CI.Top, CB.Top, CB.Mid and CB.Bottom (Table 1), this is a sign that carbon diffusion from the surrounding graphite into the cast iron has happened and that the diffusion processes of carbon are not only limited to interactions between the cast iron and the collector bar. Local deviations of temperature and chemical composition in the cast iron and collector bar have not been considered yet but play a crucial role in diffusion processes. The following paragraphs try to explain the measured differences regarding the amount of carbon in the different positions.

It is well known that carbon solubility in ferrous alloys is reduced by $\mathrm{Si}$, which can lead to an uphill diffusion of carbon [23]. With the measured Si contents in cast iron and collector bar next to the interface, it can be deduced that 
the solubility in the cast iron is lower than in the collector bar and that the raised temperatures could lead to a diffusion process where the content of carbon in the cast iron is ultimately lower than in the collector bar on the other side of the interface.

This phenomenon is also a likely reason for the higher contrast in the middle of the collector bar in relation to the position next to the cast iron. As already pointed out, EDS measurements indicate a small amount of Si which has diffused into the collector bar. Therefore, the solubility of carbon in the edge regions next to the cast iron is lower than in the middle. Assuming that the carbon diffusion has reached a point of saturation, the carbon has been pushed from the edge regions to the middle.

The lower content of carbon at CB.Bottom can be explained by a lower service temperature during the electrolysis process at the bottom of the collector bar [24], that lowers the solubility for carbon in the bottom area of the collector bar in comparison to the areas with a higher temperature. The thermodynamic simulation, which indicates a relatively low temperature of $731-803^{\circ} \mathrm{C}$ at the bottom, confirms this hypothesis (Table 2). It is to be mentioned that the calculated temperatures are not fully consistent. While it is reasonable that the temperature at the top of the collector is higher than the one at the bottom, because it is closer to the aluminium melt, no reason has been found as to why the temperature seems to be rising in the middle. This might be due to relatively high uncertainty in the measurement of the area-\% of cementite.

One important finding was the formation of pores and inclusions near the interface. The formation of the pores could be a result of the processing and is likely a combination of trapped processing gas and contraction cavities. Diffusion effects during the application time can also be responsible for an enlargement of these cavities. The inclusions (points 1 and 2, Fig. 5c) contain aluminium oxide. During the operating time or the recycling process, the cast iron could have been contaminated with aluminium and aluminium oxide.

\subsection{Electrical conductivity}

It is one of the main goals of this study to investigate the decrease of electrical conductivity, since it has an extreme influence on the energy efficiency of the electrolysis process. In general, the electrical conductivity of iron/iron alloys is highly sensitive to the content of impurities and alloying elements. Containment of non-metallic elements is likely to lead to a decrease of the electrical conductivity in relation to pure iron. The examined iron alloy has an extremely low content of alloying elements in the initial state and its electrical conductivity of $7.25 \pm 0.101 / \mu \Omega m$ is close to $7.691 / \mu \Omega m$, the electrical conductivity of pure iron at $20^{\circ} \mathrm{C}$ [25]. Compared to pure iron, the electrical conductivity of the collector bar in its initial state is lower, mainly because of the additional $\mathrm{Mn}$, which is needed for deoxidation. During operation in the electrolysis cell, carbon diffuses into the collector bar, increases the content of carbon in the matrix and eventually leads to the formation of secondary cementite. Both events contribute to the decrease in electrical conductivity. It must be mentioned that the measurements were carried out at room temperature, and the matrix is therefore not austenitic like it would be during operation, but rather pearlitic. The relative measurement results could be influenced by this.

While the effects of diffusion and change in microstructure in the collector bar over the service time lead to a local decrease in electrical conductivity, it is to be mentioned that the opposite is the case for the cast iron. This positive effect of the long-term heat treatment on the electrical conductivity can be linked to the transformation of irregularly distributed, lamellar graphite to a spherulitic shape and to the decreased content of carbon. The influence of the graphite shape within the cast iron on electrical conductivity is well known $[26,27]$. Under the assumption that the electrical current mainly passes through the matrix, lamellar graphite structures act as barriers with contact resistances and a lower electrical conductivity (0.07-0.16 $1 / \mu \Omega m$ at $\left.20^{\circ} \mathrm{C}[28]\right)$. In this case a transformation from lamellar to spherulitic graphite is beneficial for electron transport, because electrical current can bypass the barriers more easily. It must be kept in mind that a potential change regarding the total volume fraction of graphite has not been considered in this assumption and can have further influence on the electrical conductivity of the cast iron.

It was also discovered that there are pores and inclusions along the interface between cast iron and collector bar. Although this study focuses primarily on the electrical conductivity of the collector bar, the electrical conductivity of the entire electrolysis cell, and accordingly, the contact resistance at the interface must ultimately be considered. Since pores reduce the area of the cross section between cast iron and collector bar, the contact resistance is inevitably increased and therefore the electrical conductivity of the system decreases.

\section{Conclusions}

It has been shown that the high service temperatures in an electrolysis cell have an impact on the microstructure, chemical composition and consequently the electrical properties. The reason is seen in the diffusion of carbon from the surrounding cast iron. The initial state of the collector bar has an extremely low content of carbon 
and other alloying elements, which results in an electrical conductivity of $7.251 / \mu \Omega m$ at room temperature. The surrounding cast iron has a high content of $2.66 \mathrm{wt} \%$ carbon. The high temperature from the electrolysis process allows diffusion, especially of interstitial solute elements like carbon. This leads to an increased carbon content of up to $1.4 \mathrm{wt} \%$ and eventually to the formation of secondary cementite plates in the originally almost carbon free collector bar over the time of 5.4 years. Due to this extreme change of chemical composition and microstructure, the electrical conductivity decreases by up to $28 \%$ at room temperature. On the other hand, the electrical conductivity of the cast iron increases due to the shape transformation of lamellar graphite to globular graphite by up to $50 \%$. Additionally, pores and inclusions in the interface between cast iron and collector bar decrease the area of the cross section, and therefore increase the electrical resistivity.

This study is a basis for further investigations and allows suggestions for improvement of the energy efficiency of aluminium electrolysis. Therefore, further necessary investigations are proposed:

The measurements on electrical conductivity in this study were performed at room temperature. Ongoing experiments must aim at measuring this property at the service temperature between 800 and $950{ }^{\circ} \mathrm{C}$.

The discovered carbon diffusion through the whole cross section of the collector bar is accompanied by a loss of electrical conductivity. Further work must focus on prevention of carbon diffusion, for instance by a coating acting as a diffusion barrier.

In contrast to the loss of electrical conductivity in the collector bar, a raised electrical conductivity in the cast iron has been observed, due to the transformation of lamellar graphite to spherulitic graphite. Future work should try to implement other cast irons to optimize the electrical conductivity of the cell from the start.

The examined states of the collector bar are limited to the initial state and the state at end of service after 5.4 years. Future work should try to simulate diffusion processes of interstitial and substituted elements within this complex materials compound.

Acknowledgements The authors gratefully acknowledge the help of TRIMET Aluminium SE for technical devices and for providing the samples.

Funding Open Access funding provided by Projekt DEAL. This research is part of the project SynErgie (Kopernikusprojekte, 03SFK3B1) in cooperation with TRIMET Aluminium SE, funded by Bundesministerium für Bildung und Forschung.

\section{Compliance with ethical standards}

Conflict of interest The authors declare no conflicts of interest.

Open Access This article is licensed under a Creative Commons Attribution 4.0 International License, which permits use, sharing, adaptation, distribution and reproduction in any medium or format, as long as you give appropriate credit to the original author(s) and the source, provide a link to the Creative Commons licence, and indicate if changes were made. The images or other third party material in this article are included in the article's Creative Commons licence, unless indicated otherwise in a credit line to the material. If material is not included in the article's Creative Commons licence and your intended use is not permitted by statutory regulation or exceeds the permitted use, you will need to obtain permission directly from the copyright holder. To view a copy of this licence, visit http://creativecommons .org/licenses/by/4.0/.

\section{References}

1. Ostermann $F$ (2014) Anwendungstechnologie Aluminium, 3rd edn. Springer, Berlin, p 744

2. Kvande H (1989) Trends and perspectives of the Hall-Héroult process. Magyar Alum 26:382-389

3. Carbone Savoie (2008) REF:B1100-Rev, cathode HC10

4. Tao WJ, Wang ZW, Gao BL, Shi ZN, Hu XW, Cui JZ (2014) Numerical simulation electric distribution in aluminum reduction cell with vertical collector bars. Metalurgija 53:17-20

5. Cubeddu A, Nandana V, Janoske U (2019) A numerical study of gas production and bubble dynamics in a Hall-Héroult reduction cell. Light Met 2019:605-613. https://doi.org/10.1007/9783-030-05864-7 75

6. Haraldsson J, Johansson MT (2018) Review of measures for improved energy efficiency in production-related processes in the aluminium industry-from electrolysis to recycling. Renew Sustain Energy Rev 93(8):525-548. https://doi.org/10.1016/j. rser.2018.05.043

7. Lorentsen OA (2014) 125 years of the Hall-Héroult processWhat made it a success? Molten Salts Chem Technol. https:// doi.org/10.1002/9781118448847.ch1k

8. Cus Z, Sibila A (2008) 20 years of continues improvements in TALUM smelter. TMS Light Met 467-471

9. Feiya Y, Dupuis M, Jianfei Z, Shaoyong R, Sadler BA (2013) In depth analysis of energy-saving and current efficiency improvement of aluminum reduction cells. Light Met 2013:537-542. https://doi.org/10.1007/978-3-319-65136-1

10. Jianping $P$, Naixiang F, Shaofeng F, Jun $L$, Xiquan $O$ (2011) Development and application of an energy saving technology for aluminum reduction cells. Light Met 2011:1023-1027. https://doi. org/10.1007/978-3-319-48160-9_174

11. Naixiang F, Jianping $P$, Yaowu W, Yuezhong D, Xian'an L (2013) Energy reduction technology for aluminum electrolysis: choice of the cell voltage. Light Met 2013:549-552. https://doi. org/10.1007/978-3-319-65136-1_93

12. Dongfang $Z$, Xiaodong $Y$, Wie L (2012) Development and application of SAMI's low voltage energy-saving technology light metals 2012:607-612. https://doi.org/10.1007/978-3-319-48179 $-1-103$

13. Shakhrai $S$, Mikhalev $Y$, Kalinovskaya $T$, Arkhipov $G$, Ivanova A (2016) Investigation and choice of materials for the electrical insulation of the steel bloom of an aluminum electrolyzer. Metallurgist 60:622-628. https://doi.org/10.1007/s1101 5-016-0341-4 
14. Chauke L, Garbers-Craig AM (2013) Reactivity between carbon materials and electrolyte based on industrial and laboratory data. Carbon 58:40-45. https://doi.org/10.1016/j.carbo n.2013.02.023

15. Tschöpe K, Schøning C, Rutlin J, Grande T (2012) Chemical degradation of cathode linings in Hall-Héroult cells-an autopsy study of three spent pot linings. Metall Trans B 43(2):290-301. https://doi.org/10.1007/s11663-011-9604-4

16. Solheim A, Schøning C, Skvbakmoen E (2016) Reactions in the bottom lining of aluminium reduction cells. Essent Read Light Met 4:972-977. https://doi.org/10.1002/9781118647745.ch129

17. Heraeus Electro-Nite International NV, Therm Anal Cast Iron https://www.heraeus.com/media/media/hen/media-hen/produ cts-hen/iron/thermal_analysis_of_cast_iron.pdf. Accessed 20 April 2020

18. Kernebeck S, Deuerler F, Weber S (2019) Investigation of the application related diffusion reaction on the cathode side of an Al electrolysis cell (in german). Pract Metallogr 53:67-72

19. DIN EN ISO 643, „Stahl - Mikrophotographische Bestimmung der erkennbaren Korngröße", Beuth Verlag GmbH (2013)

20. TRIMET Aluminium SE, 2018

21. Bargel HJ, Schulze G (2018) Engineering materials science (in German), 12th edn. Springer, Berlin, p 33

22. Batz W, Mead HW, Birchenall CE (1952) Diffusion of silicon in iron. JOM 10:1070
23. Darken LS (1949) Diffusion of carbon in austenite with a discontinuity in composition. Trans Aime 53:430-438

24. Tao W, Gao B, Sh Z, Hu X (2014) Impact of the usage of a slotted collector bar on thermoelectric field in a 300-kA aluminum reduction cell. JOM 67(2):322-329. https://doi.org/10.1007/ s11837-014-1195-5

25. Hornbogen E, Eggeler G, Werner W (2008) Engineering materials (in German), 9th edn. Springer, Berlin, p 242

26. Söhnchen E (1943) The electrical and thermal conductivity of cast iron (in German) Archiv für das Eisenhüttenwesen 5:223-229

27. Masumoto $\mathrm{H}$ (1927) On the electrical and thermal conductivities of carbon steel and cast iron. Sci Rep Tohoku Imperial Univ 16:417-435

28. Buerschaper RA (1944) Thermal and electrical conductivity of graphite and carbon at low temperatures. J Appl Phys 15(5):452-454

Publisher's Note Springer Nature remains neutral with regard to jurisdictional claims in published maps and institutional affiliations. 